International Journal of English Literature and Social Sciences
Vol-6, Issue-1; Jan-Feb, 2021

\title{
On Thoreau's Contradictory View of Nature
}

\section{Du Haixia}

School of Foreign Languages, Xinxiang Medical University, Henan, China

Received: 03 Oct 2020; Received in revised form: 25 Jan 2021; Accepted: 19 Feb 2021; Available online: 27 Feb 2021

C2021 The Author(s). Published by Infogain Publication. This is an open access article under the CC BY license

(https://creativecommons.org/licenses/by/4.0/).

\begin{abstract}
This paper tries to analyze Thoreau's contradictory view of nature: on the one hand, Thoreau admired nature and wanted to be close to nature and opposed against the American consumer culture, on the other hand, he still held hopes on civilization. According to Thoreau, wilderness and refinement were not fatal extremes but equally beneficent influences Americans would do well to blend.
\end{abstract}

Keywords-Thoreau, nature, civilization, contradictory.

\section{INTRODUCTION}

On April 23, 1851, Henry David Thoreau, slight and stooped, ascended the lecture platform before the Concord Lyceum. "I wish," he began, "to speak a word for nature, for absolute freedom and wilderness." He declared, "let me live where I will. On this side is the city, on that the wilderness, and ever I am leaving the city more and more, and withdrawing into the wilderness." Near the end of the address, he concerned his message in eight words," in wilderness is the preservation of the world." Thoreau's natural philosophy is also perfectly manifested in his representative work Walden. Through the close reading, readers may get a little confused, since his view on nature seems self-contradictory. He encouraged people to go back to nature and also respected civilization at the same time. This short paper will try to analyze his contradictory view on nature.

\section{HIS LOVE OF NATURE}

Thoreau harbors a great love for nature. He is extremely happy in walking the woods to observe the birds and the small animals, noting the phenomena of the seasons talking with a simple Canadian wood chopper who worked happily felling trees for concord fireplaces and cultivating his little garden, or as he puts it, "making the earth say beans instead of grass." In Walden, he showed that wild country offered the necessary freedom and solitude. Moreover, it offered life stripped down to essentials. Because of this rawness, wilderness was the best environment in which to "see ourselves, and work and wedge our feet downward through the mud and slush of opinions, and prejudice and tradition and delusion ...through Paris and London, trough New York and Boston.... till we come to a hard bottom and rocks in place, which we call reality. "With this in mind Thoreau sought Walden Pond. He declared, "I went to the woods, because I wish to live deliberately." He was sure that the wilderness, though not so admirable as life, was at least better than that life of quiet desperation which results from too much concentration on getting ahead in the material sense.

The lesson Thoreau had taught himself, and which he tried to teach others was summed up in the one word 'simplify'. That meant simplify the outward circumstances of your life, simplify your needs and your ambitions, and learn to delight in the simple pleasures which the world of 
nature affords. It also meant to scorn public opinion; refuse to accept the common definitions of success, refused to be moved by the judgment of others. Simplicity is more than a mode of life for Thoreau; it is a philosophical ideal as well. In his "Economy" chapter, Thoreau asserts that a feeling of dissatisfaction with one's possessions can be resolved in two ways: one may acquire more, or reduce one's desires. Thoreau looks around at his fellow Concord residents and finds them taking the first path, devoting their energies to making mortgage payments and buying the latest fashions. He prefers to take the second path of radically minimizing his consumer activity. Thoreau patches his clothes instead of buying new ones and dispenses with all accessories he finds unnecessary. For Thoreau, anything more than what is useful is not just an extravagance, but a real impediment and disadvantage. He builds his own shack instead of getting a bank loan to buy one, and enjoys the leisure time that he can afford by renouncing larger expenditures. Ironically, he points out, those who pursue more impressive possessions actually have fewer possessions than he does, since he owns his house outright, while theirs are technically held by mortgage companies. He argues that the simplification of one's lifestyle does not hinder such pleasures as owning one's residence, but on the contrary, facilitates them. From this evidence the readers can see that Thoreau's natural view is nature-oriented and he belongs to group of anticivilization.

\section{HIS NOSTALGIA FOR CIVILIZATION}

While Thoreau was unprecedented in his praise of the American wilderness, his enthusiasm was not undiluted; some of the old antipathy and fear lingered even in his thought. The question became clear; was it possible to combine the hardiness of these savages with the intellectualness of the civilization? Put it another way, could men live so as to secure all the advantage of civilization with the benefits of cultural refinement. An access of either condition must be avoided. The vitality, heroism, and toughness that came with a wilderness condition had to be balanced by the delicacy, sensitivity, and intellectual and moral growth characteristic of civilization. He said, "The natural remedy is to be found in the proportion which the night bears to the day, the winter to the summer, thought to experience." In Walden, he reported recognizing in himself "an instinct toward a higher, or as it is named, spiritual life... And another toward a primitive, rank and savage one." Rejoicing in both, Thoreau strove to make himself, as his bean field at the pond, half cultivated. "I would not," he explained, "have.... Every part of a man cultivated, any more than I would have any acre of earth" some of each, of course, should be controlled and tilled, but along with the tame must be blended some wilderness or wilderness as a strength-giving fertilizer. As long as its potency was partially diluted, superb crops could grow. For his own part regarding wilderness Thoreau felt he lived a sort of border life. Occasionally he sought the wilds for nourishment and the opportunity to exercise his savage instinct, but at the same time he knew he could nor remain permanently. He said, "a civilized man...must at length pine there, like a cultivated plant, which clasps its fibers about a crude and undissolved mass of peat." Though the very intensity of Thoreau's imagination made to retreat to Walden Pond a legend and a symbol, he was no Robison Crusoe. The cabin was only a mile and a half from the main road leading to it. He had many visitors and he walked often into Concord. His eulogy of a humble lifestyle does not lead him to solidarity with the working poor or to any sort of community-based feeling; rather, it makes him a bit isolated, strangely distant from his neighbors. One point should be noticed. the civilization he advocated mainly refers to the American elite culture. Thoreau consistently criticizes neighbors he considers bestial, although he theoretically endorses their simplicity. He praises the grand woodchopper Alex Therien, for example, only to abruptly dismiss Therien as being too uncouth, too immersed in "animal nature." The unfairness of this dismissal leaves a bitter taste in our mouths, making us wonder whether Thoreau would quietly reject other poor workers as excessively animal-like. Similarly, his preachy and rather condescending lecture toward the humble Field family, in whose house he seeks shelter from a rainstorm, shows no signs of any desire to contact with the poor on an equal footing with himself. He may want to be their instructor and guide, but not really their friend or comrade. Most damning is Thoreau's unpleasant, almost racist remark that the Fields' poverty is an "inherited" Irish 
trait, as if implying that non-Anglo immigrants are genetically incapable of the noble frugality and resourcefulness that distinguishes Thoreau.

\section{CONCLUSION}

From the analysis above, readers can see the contradictory view of nature: on the one hand, Thoreau admired nature and wanted to be close to nature and opposed against the American consumer culture, on the other hand, he still held hopes on civilization. According to Thoreau, wilderness and refinement were not fatal extremes but equally beneficent influences Americans would do well to blend. With this concept Thoreau led the intellectual revolution that was beginning to invest wilderness with attractive rather than repulsive qualities.

\section{REFERENCES}

[1] Chang, Yaoxin. A Survey of American Literature [M].Tianjin:Nankai University Press,2016.

[2] Myerson,Joel(ed.).The Cambridge Companion to Henry David Thoreau[M].Cambridge: The Cambridge University Press, 1995.

[3] Sayer, Robert F.(ed). New Essays on Walden[M]. Cambridge: Cambridge University Press, 1992. 